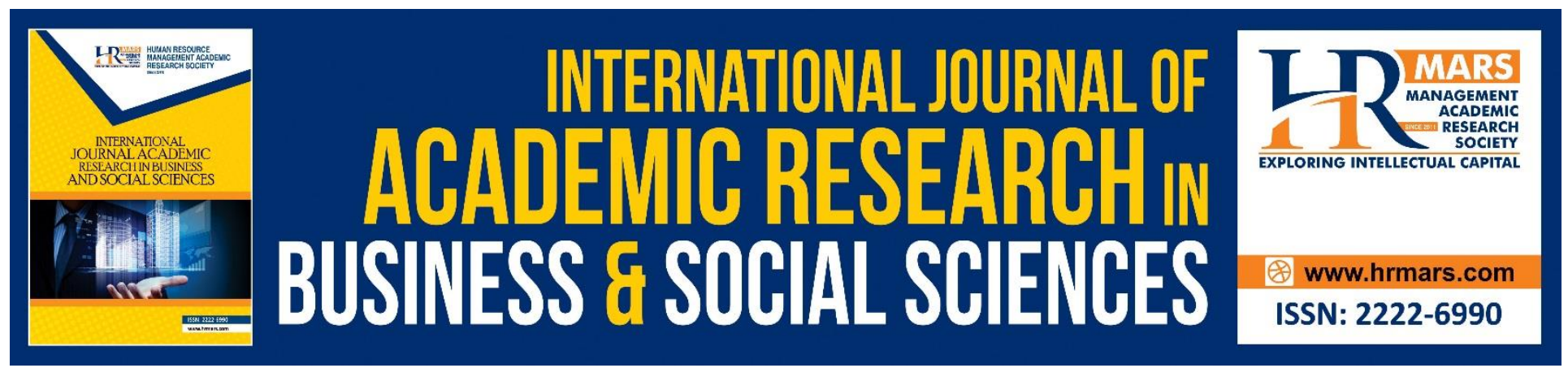

\title{
The Effect of Entrepreneurial Orientation, Product Innovation, and Information Technology on the SME's Performance Facing the Era of Industrial Revolution 4.0: Intellectual Capital as Mediator
}

\section{Zulfa Indana, Setyabudi Indartono}

To Link this Article: http://dx.doi.org/10.6007/IJARBSS/v10-i8/7610

DOI:10.6007/IJARBSS/v10-i8/7610

Received: 09 June 2020, Revised: 27 June 2020, Accepted: 12 July 2020

Published Online: 10 August 2020

In-Text Citation: (Indana, \& Indartono, 2020)

To Cite this Article: Indana, Z., \& Indartono, S. (2020). The Effect of Entrepreneurial Orientation, Product Innovation, and Information Technology on the SME's Performance Facing the Era of Industrial Revolution 4.0: Intellectual Capital as Mediator. International Journal Academic Research in Business and Social Sciences. 10(8), 683-698.

\section{Copyright: @ 2020 The Author(s)}

Published by Human Resource Management Academic Research Society (www.hrmars.com)

This article is published under the Creative Commons Attribution (CC BY 4.0) license. Anyone may reproduce, distribute, translate and create derivative works of this article (for both commercial and non-commercial purposes), subject to full attribution to the original publication and authors. The full terms of this license may be seen at: http://creativecommons.org/licences/by/4.0/legalcode

\section{Vol. 10, No. 8, 2020, Pg. 683 - 698}




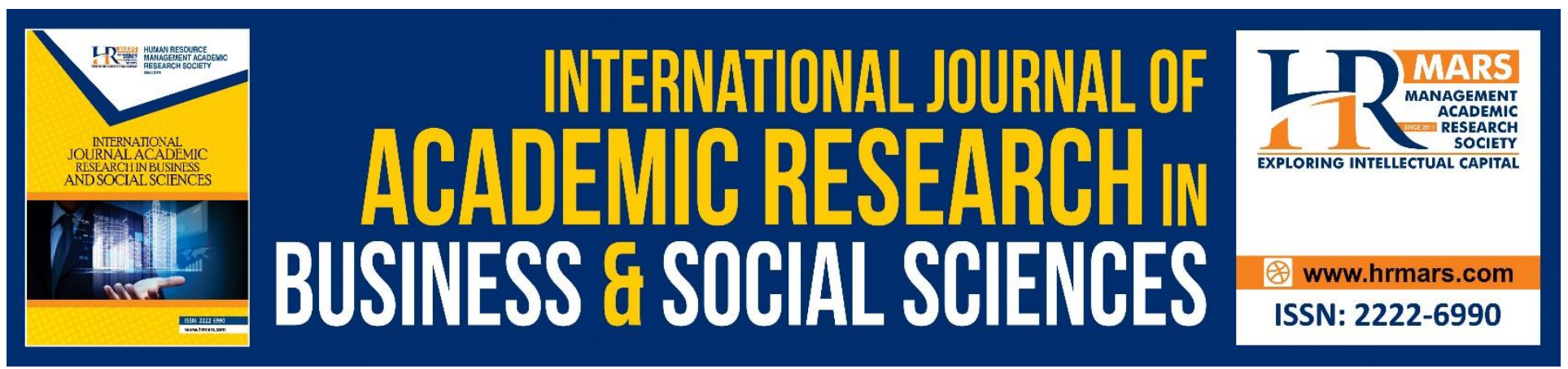

\title{
The Effect of Entrepreneurial Orientation, Product Innovation, and Information Technology on the SME's Performance Facing the Era of Industrial Revolution 4.0: Intellectual Capital as Mediator
}

\author{
Zulfa Indana ${ }^{1}$, Setyabudi Indartono ${ }^{2}$ \\ ${ }^{1}$ Graduate School Program, Yogyakarta State University, Indonesia, ${ }^{2}$ Management Department, \\ Yogyakarta State University, Indonesia \\ Email: zulfaa.Indana510@gmail.com
}

\section{Abstract}

This paper aims to analyze the effect of entrepreneurial orientation, product innovation, and information technology on SME's performance facing the era of industrial revolution 4.0 with intellectual capital as mediation variable. This research is associative causal research using the quantitative approach. The subjects of the research are owners of convection SME's in Kebumen Regency - Central Java, with the number of population in this research 155 . The number of samples in this research 112 . The sampling technique using simple random sampling technique. The data collection used a questionnaire that had been tested for validity and reliability. The data analysis technique use multiple regression.

The results of the research show that entrepreneurial orientation, product innovation, and information technology has positive and significant effect on SME's performance. Intellectual capital has positive and significant effect on SME's performance. Intellectual capital mediates the effect of entrepreneurial orientation, product innovation, and information technology on SME's performance. From these results, it can be concluded that entrepreneurial orientation, product innovation, information technology, and intellectual capital have a large contribution to the better business performance in SME's.

Keywords: Entrepreneurial Orientation, Information Technology, Product Innovation, Intellectual Capital, SME's Performance.

\section{Introduction}

The development of science and technology has been increasingly rapid, especially in the era of the industrial revolution 4.0 at this time, where there have been many developing technologies that exist in various sectors such as business, education, health, and many other sectors in this life that can not be separated from the development technology. Industrial revolution 4.0 according to Prasetyo and Sutopo (2018) is a comprehensive transformation that exists in all aspects of production 
INTERNATIONAL JOURNAL OF ACADEMIC RESEARCH IN BUSINESS AND SOCIAL SCIENCES Vol. 10, No. 8, 2020, E-ISSN: 2222-6990 @ 2020 HRMARS

that exist in the industry through the integration of digital technology and the internet with conventional industries. According to Herman (2016) the industrial revolution 4.0 is marked by the development of the Internet of Things (IoT) or the Internet of People (IoP) where with the connectivity and digitalization it will be able to make the value of a product produced by entrepreneurs become more efficient and the quality of products becomes better.

Small and Medium Enterprises (SME's) are the main sectors that have a large contribution to the economy in Indonesia, where SME's are considered strong in the face of crisis shocks. In addition, SME's also have many roles, especially in terms of employment opportunities and sources of income for the poor, income distribution, reducing unemployment, poverty, and rural economic development. The industrial revolution 4.0 brings benefits to business people, because they can easily integrate business activities by utilizing technology, however on the other side industrial revolution 4.0 is also a challenge for business people, especially for business people who can't to adapt the development of existing technology. The tight competition in the era of industrial revolution 4.0 is not only felt by large-scale companies, but the intense competition is also felt by SME's. In the era of Industrial Revolution 4.0, SME's are required to have dynamic capabilities and strategies that are able to capture new business opportunities, however, in reality the demands in the current business environment are still difficult for SMEs to fulfill. According to Matsuno \& Mentzer (2002) Quality SME's are still low caused by several internal problems in SME's. Some of the problems faced by SME's are the lack of product innovation, difficulties in marketing products, lack of ability to implement information technology, lack of entrepreneurial orientation and managerial roles in managing business in a rapidly changing business environment. Therefore, SME's need to pay attention to several factors to be able to support the performance of their business in order to survive and win competition in the era of the industrial revolution 4.0.

Performance is a level of achievement achieved by business people in a certain period that is reflected in the level of output generated both in quantity and quality (Anggad wita \& Mustafid, 2013). The performance of SME's can improve if supported by various factors, one of them is entrepreneurial orientation. Jayaningrum (2018) defines entrepreneurial orientation as a process, practice, and activity of a business carried out using product innovation, risk taking, and proactive efforts to win competition in the market. In the context of SME's, entrepreneurial orientation has a strong relationship with the performance of SME's (Lie et al, 2008). That is because SME's have the ability to respond quickly to any opportunities or threats that exist in the business. SME's who implement entrepreneurial orientation on their business activities will have better business performance than SME's who not adopt entrepreneurial orientation (Wardi, 2015). Matsuno \& Mentzer (2002) argues that entrepreneurial orientation is a factor that contributes to improving business performance. SME's who have a strong entrepreneurial orientation, will be able to develop new product and service concepts towards the needs of existing customers. So, the higher entrepreneurial orientation the SME's have, the higher the business performance of the SME's they produce.

Another factor that contributes to improving the performance of SME's is product innovation. Atalay (2013) argues that product innovation is the introduction and development of new types of goods that are different from existing ones and complement the shortcomings of existing goods by emphasizing quality. The results of research conducted by Herlambang and Mawardi (2017) stated that product innovation has a positive effect on SME's performance. The results of the research explained that the better and more frequent SME's who innovate both by creating and developing 
INTERNATIONAL JOURNAL OF ACADEMIC RESEARCH IN BUSINESS AND SOCIAL SCIENCES Vol. 10, No. 8, 2020, E-ISSN: 2222-6990 @ 2020 HRMARS

new ideas, creating attractive designs, adding new products at every opportunity, and actively developing the quality of their products, then will be able to improve the performance of these SME's.

The use of information technology is a positive approach in promoting SME's as well as strategies in the field of management to facilitate the operations of SME's (Dahnil, 2014). Adopting technology can bring benefits to the efficiency, effectiveness, innovation development of SME's, and ultimately the performance of SME's will increase. The results of another research conducted by Adietya (2017) which states that information technology has a positive effect on SME performance. So, the use of information technology in SMEs will be able to support the performance of these SMEs.

Another factor that is no less important is intellectual capital, which is one of the factors that influence the performance of SME's. In SME's, intellectual capital is considered very important for business development which will ultimately be able to improve welfare by increasing the performance of the business being run. Intellectual capital is one of the key determinants of the value of a business. The results of research conducted by Alipour (2012) states that intellectual capital has a positive and significant effect on the performance of SMEs. Intellectual capital (intellectual capital) becomes the main asset that determines success in business competition (Bontis, 2004).

Many factors and variables affect business performance, but in this research, the author will focus more on discussing the variables of entrepreneurial orientation, product innovation, information technology, and intellectual capital to assess whether these variables can really affect business performance in SME's. Although the themes and variables used in this research which include the variables of entrepreneurial orientation, product innovation, information technology, intellectual capital, and SME's performance have been widely used in previous studies, but the results obtained are not the same. Moreover, there is still rarely research that discusses the problem of the contribution of intellectual capital to business performance in the SME's sector.

Grand theory of this research is using theory Resource Based View (RBV). Ferreira (2007) argues that the RBV theory explains the ownership of internal resources of the company, where the success of an effort is determined by the strengths and weaknesses that exist within the company. The success of a business is determined by the ownership of resources and the capability of the company in turning existing resources into economic benefits. This paper aims to analyze the effect of entrepreneurial orientation, product innovation, and information technology on SME's performance facing the era of industrial revolution 4.0 with intellectual capital as mediation variable. This research is considered important to be carried out in order to know and provide an overview of what variables can make SME's achieve their best business performance.

\section{Research Framework and Hypothesis}

\section{a. Relationship Between Entrepreneurial Orientation on SME's Perfomance}

Abbas (2014) defines performance as the results of work achieved by business people expressed based on sales volume, sales growth rate, and customer growth rate, profit growth rate. The performance of SME's can increase in supported of various factors, one of which is entrepreneurial orientation. In the context of SME's, entrepreneurial orientation has a strong relationship with SME's performance (Lie et al, 2008), because SME's have the ability to respond quickly to any opportunities or threats that exist in the business. SME's that implements entrepreneurial orientation in running business will have a better business performance than doesn't adopt an entrepreneurial orientation (Wardi, 2015). The results of research by Frank (2010) and Awang (2009) which states that entrepreneurial orientation has no influence on business 
INTERNATIONAL JOURNAL OF ACADEMIC RESEARCH IN BUSINESS AND SOCIAL SCIENCES Vol. 10, No. 8, 2020, E-ISSN: 2222-6990 @ 2020 HRMARS

performance. However, the results of another study by Karami (2019); Mahmood and Hanafi (2013); Al Swidi (2011) proves that entrepreneurial orientation has a significant positive effect on business performance. Matsuno \& Mentzer (2002) argues that entrepreneurial orientation is a factor that contributes to improving business performance. Thus, it can be said that SME's that are able to survive in business competition are those who have an entrepreneurial spirit such as being active, dare to take risks, and innovating to improve the performance of the business being run

$H 1$ = Entrepreneurial orientation has a possitive effect on the SME's performance

\section{b. Relationship Between Product Innovation on SME's Perfomance}

Atalay (2013) defines that product innovation is the introduction and development of new types of goods and services that are different from those that existed before and complement the shortcomings of existing goods or services by emphasizing in terms of quality. Research conducted by Herlambang and Mawardi (2017) states that innovation has a positive effect on SME's performance. In this research explained that the better and more frequent SME's who innovate by creating and developing new ideas, creating attractive designs, adding new products at every opportunity, and actively developing the quality of their products, then will be able to improve the performance of these SME's. This shows that the better and more often SME's innovate by creating new designs that are more attractive and unique and always control the quality of the products, will be able to improve the performance of SMEs.

H2 = Product innovation has a positive effect on the SME's performance

\section{c. Relationship Between Information Technology on SME's Perfomance}

The use of information technology is one of the positive approaches in promoting SME's as well as strategies in the field of management to facilitate operations run by SME's (Dahnil, 2014). Adopting technology can bring benefits to the efficiency, effectiveness, innovation development of SMEs, and ultimately the performance of SME's will increase. According to Adietya (2017) said that information technology has a positive effect on SME's performance.

H3 = Information technology has a positive effect on the SME's performance

\section{d. Relationship Between Intellectual Capital on SME's Perfomance}

Intellectual capital is one of the keys to determining success in business. The results of research by Indriastuti (2012) states that there is a positive relationship between intellectual capital and the performance of SME's. Alipour (2012) states that intellectual capital has a positive and significant effect on the SME's performance. Intellectual capital (intellectual capital) becomes the main asset that determines success in business competition (Bontis 2004).

H4 = Intellectual capital a positive effect on the SME's performance

\section{e. Mediation Intellectual Capital Between Entrepreneurial Orientation, Product Innovation, and Information Technology}

Entrepreneurial orientation, product innovation, and information technology will be able to improve business performance on SME's through the role of intellectual capital owned by the company. To achieve good business performance, the role of an entity's internal factors is needed. According to Ferreira (2007) success in doing business is determined by the resources owned and the capability of a business organization to convert existing resources into an economic benefit and 
INTERNATIONAL JOURNAL OF ACADEMIC RESEARCH IN BUSINESS AND SOCIAL SCIENCES Vol. 10, No. 8, 2020, E-ISSN: 2222-6990 @ 2020 HRMARS

success or failure of a business is determined by the strengths and weaknesses that exist in the internal business. Intellectual capital is the key to achieving progress in a business. The performance of SME's will improve if in running a business, SME's have an entrepreneurial orientation, product innovation, information technology that is supported by good intellectual capital management in the form of human capital, structural capital, and relational capital. Belkaoui (2003) argue that the potential strategy in improving business performance is to manage strategic assets in an organization. This is accordance with the theory of Resources Based View which consider that the resources and ability to run a business are considered to be important for business continuity. The assumption of this theory is about how a business can compete with another business by managing the resources of the company in accordance with the company's ability to achieve competitive advantage and better business performance.

H5 = Intellectual capital mediates the relationship between entrepreneurial orientation and SME's performance

H6 = Intellectual capital mediates the relationship between product innovation and SME's performance

$H 7$ = Intellectual capital mediates the relationship between information technology and SME's performance

The Research Framework is made as Follows

Figure 1 Research Framework

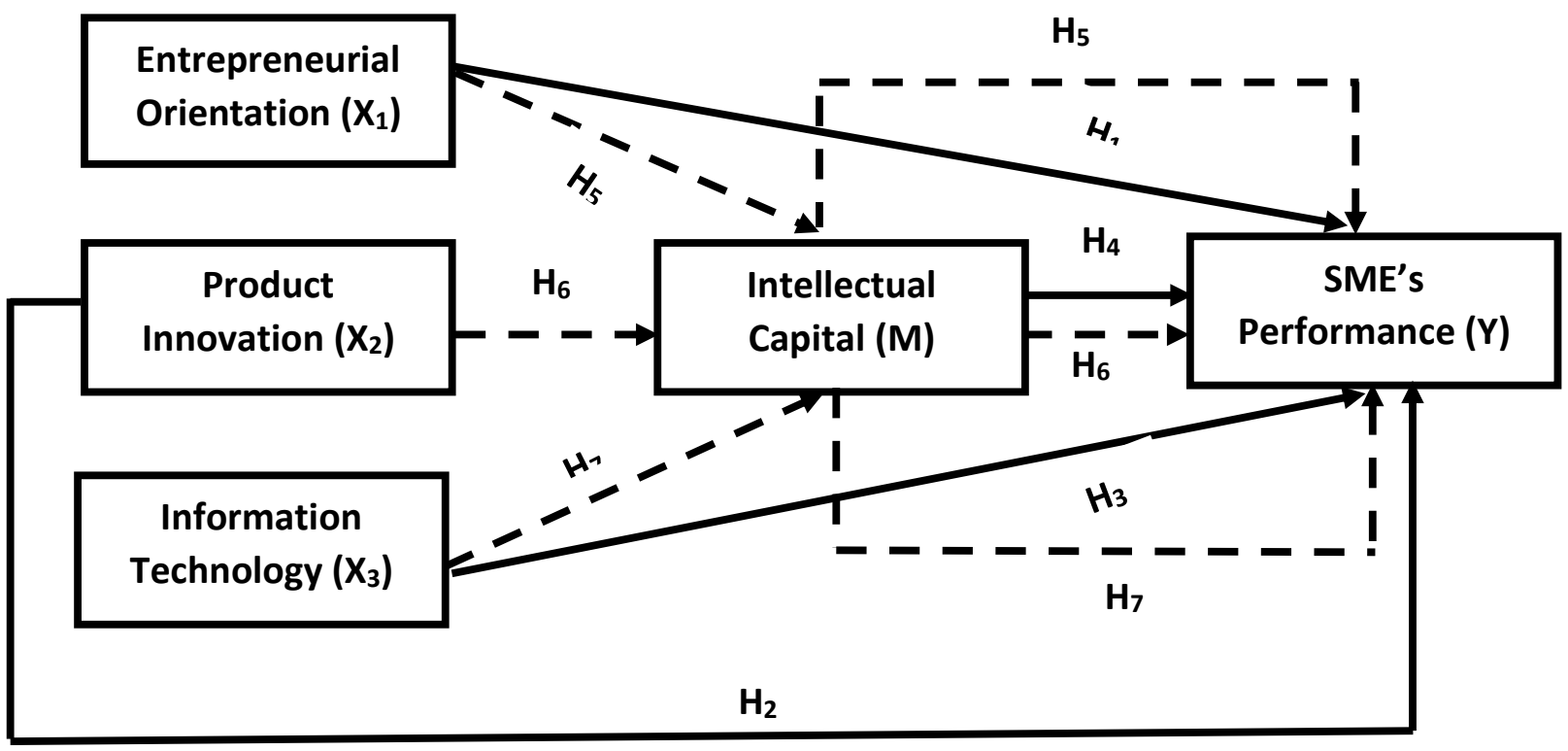

NOTE :

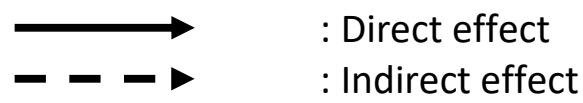

Methods

This research is a causal associative research using a quantitative approach. Data collection techniques in this research were using a questionnaire. The population in this research were all 
INTERNATIONAL JOURNAL OF ACADEMIC RESEARCH IN BUSINESS AND SOCIAL SCIENCES Vol. 10, No. 8, 2020, E-ISSN: 2222-6990 @ 2020 HRMARS

owners of convection SME's located in Kebumen Regency-Central Java, with 155 SME's units. Based on calculations using the Slovin formula, the number of samples that were respondents in this research were 112 owners of convection SME's. The sampling technique in this research uses simple random sampling technique. The selection of the sampling technique is because by using the technique each sampling unit as an element of the population has the same opportunity to be sampled in the research. The sampling procedure is done by using a lottery. Validity testing in this research was carried out using Confirmatory Factor Analysis (CFA), while the reliability test was based on the value of Cronbach's Alpha. The data analysis technique used in this research was to use multiple linear regression analysis using SPSS software version 21.

\section{Result and Discussion}

The statement items used in this research were 36 statements that had to be answered by the respondents. However, after testing the validity there are only 34 valid items. Test the validity of statement items used in this research using the CFA (Confirmatory Factor Analysis) by looking at the results of the Kaiser Meyer-Olkin (KMO) test. The following are the validity results from 34 statement items that are declared valid as follows

Table 1 KMO Value of Validity Test Results

\begin{tabular}{lrr}
\hline \multicolumn{3}{c}{ KMO and Bartlett's Test } \\
\hline Kaiser-Meyer-Olkin Measure of Sampling & .646 \\
Adequacy. & & \\
Bartlett's Test of & Approx. Chi-Square & 2721.597 \\
Sphericity & Df & 561 \\
& Sig. & .000 \\
\hline
\end{tabular}

Based on the results seen in table 1 , the $\mathrm{KMO}$ value is 0.646 . The $\mathrm{KMO}$ value obtained is 0.646 which is greater than 0.5 . This shows that the factor analysis is feasible because according to Ghozali (2011) if a high index value ranges between 0.5-1.0, then factor analysis is feasible and vice versa if it is less than 0.5 , then factor analysis is not worth doing. 
INTERNATIONAL JOURNAL OF ACADEMIC RESEARCH IN BUSINESS AND SOCIAL SCIENCES Vol. 10, No. 8, 2020, E-ISSN: 2222-6990 @ 2020 HRMARS

Table 2 Value Factors Loading Variables

\begin{tabular}{|c|c|c|c|c|c|c|}
\hline \multirow{3}{*}{ Variabel } & \multicolumn{6}{|c|}{ Rotated Component Matrix ${ }^{a}$} \\
\hline & \multirow{2}{*}{ Item } & \multicolumn{5}{|c|}{ Component } \\
\hline & & 1 & 2 & 3 & 4 & 5 \\
\hline \multirow{9}{*}{ SME's Performance } & KU1 & & & 0.546 & & \\
\hline & KU2 & & & 0.868 & & \\
\hline & KU3 & & & 0.655 & & \\
\hline & KU4 & & & 0.632 & & \\
\hline & KU5 & & & 0.587 & & \\
\hline & KU6 & & & 0.544 & & \\
\hline & KU7 & & & 0.843 & & \\
\hline & OR1 & 0.879 & & & & \\
\hline & OR2 & 0.910 & & & & \\
\hline \multirow{7}{*}{ Entrepreneurial Orientation } & OR3 & 0.531 & & & & \\
\hline & OR4 & 0.885 & & & & \\
\hline & OR5 & 0.855 & & & & \\
\hline & OR6 & 0.779 & & & & \\
\hline & IP1 & & & & 0.693 & \\
\hline & IP2 & & & & 0.755 & \\
\hline & IP3 & & & & 0.840 & \\
\hline \multirow[t]{6}{*}{ Product Innovation } & IP4 & & & & 0.644 & \\
\hline & IP5 & & & & 0.694 & \\
\hline & IP6 & & & & 0.583 & \\
\hline & IP7 & & & & 0.759 & \\
\hline & TI1 & & & & & 0.691 \\
\hline & $\mathrm{T} 12$ & & & & & 0.557 \\
\hline \multirow{4}{*}{ Information Technology } & TI3 & & & & & 0.718 \\
\hline & TI4 & & & & & 0.822 \\
\hline & TI5 & & & & & 0.859 \\
\hline & TI6 & & & & & 0.661 \\
\hline \multirow{8}{*}{ Intellectual Capital } & MI1 & & 0.540 & & & \\
\hline & MI4 & & 0.653 & & & \\
\hline & MI5 & & 0.514 & & & \\
\hline & MI6 & & 0.637 & & & \\
\hline & MI7 & & 0.781 & & & \\
\hline & MI8 & & 0.868 & & & \\
\hline & MI9 & & 0.776 & & & \\
\hline & MI3 & & 0.733 & & & \\
\hline
\end{tabular}

Based on the results of the validity test as shown in table 2, the results are obtained that each of the statement items on the research instrument is valid because it has a value above 0.5. This is evidenced by the acquisition of the correlation value of each statement item where the correlation value of each statement item is more than 0.5 , so 34 items are declared valid. 
INTERNATIONAL JOURNAL OF ACADEMIC RESEARCH IN BUSINESS AND SOCIAL SCIENCES Vol. 10, No. 8, 2020, E-ISSN: 2222-6990 @ 2020 HRMARS

The results of the reliability test on the questionnaire from the entrepreneurial orientation research variables, product innovation, information technology, intellectual capital on the performance of SMEs were carried out using SPSS 21. From the results of the tests conducted obtained the following results

Table 3 Reliability Test Results

\begin{tabular}{lc}
\hline \multicolumn{1}{c}{ Variable } & Cronbach's Alpha \\
\hline SME's Performance & 0.810 \\
Entrepreneurial Orientation & 0.919 \\
Product Innovation & 0.730 \\
Information Technology & 0.821 \\
Intellectual Capital & 0.820 \\
\hline
\end{tabular}

Based on the results of the reliability test, the results obtained that the value obtained has met the criteria of good reliability because the value of the Cronbach's Alpha > of 0.7. So, from the results of the reliability test conducted, it can be concluded that the research questionnaire is reliable.

\section{Regression Analysis}

The following are the results of the analysis using multiple regression analysis that has been carried out using the SPSS 21 program, as follows:

Table 4 Summary of Regression Analysis Results

\begin{tabular}{|c|c|c|c|c|c|c|}
\hline $\begin{array}{c}\text { Control, } \\
\text { Independent, and } \\
\text { Mediation } \\
\text { Variables }\end{array}$ & Step 1 & Step 2 & Step 3 & Step 4 & Step 5 & Step 6 \\
\hline Gender & -0.074 & -0.074 & -0.036 & 0.029 & 0.090 & $0.097^{*}$ \\
\hline Age & $0.199 *$ & 0.126 & 0.166 & 0.094 & -0.016 & -0.032 \\
\hline Level of education & -0.098 & -0.119 & -0.122 & -0.041 & -0.043 & -0.052 \\
\hline Business duration & 0.155 & 0.142 & 0.106 & 0.075 & 0.093 & 0.062 \\
\hline $\begin{array}{l}\text { Entrepreneurial } \\
\text { Orientation }\left(X_{1}\right)\end{array}$ & - & $0.418 * * *$ & - & - & - & $0.121 *$ \\
\hline $\begin{array}{l}\text { Product Innovation } \\
\left(X_{2}\right)\end{array}$ & - & - & $0.329 * * *$ & - & - & $0.107^{*}$ \\
\hline $\begin{array}{l}\text { Information } \\
\text { Technology }\left(X_{3}\right)\end{array}$ & - & - & - & $0.616^{* * *}$ & - & $0.190 * * *$ \\
\hline $\begin{array}{l}\text { Intellectual capital } \\
\text { (M) }\end{array}$ & - & - & - & - & $0.872^{* * *}$ & $0.673 * * *$ \\
\hline $\mathbf{R}^{2}$ & $0.128 * *$ & $0.297 * * *$ & $0.231 * * *$ & $0.459 * * *$ & $0.783 * * *$ & $0.818 * * *$ \\
\hline$\Delta R^{2}$ & 0.128 & 0.169 & 0.103 & 0.331 & 0.655 & 0.690 \\
\hline
\end{tabular}


INTERNATIONAL JOURNAL OF ACADEMIC RESEARCH IN BUSINESS AND SOCIAL SCIENCES Vol. 10, No. 8, 2020, E-ISSN: 2222-6990 @ 2020 HRMARS

Based on testing the hypotheses listed in table 4, the results obtained that in the second step the beta coefficient value produced was equal to 0.418 with a significance value $p<0.001$. This shows that entrepreneurial orientation has a positive and significant effect on the SME's performance. The delta coefficient of determination value $\left(\Delta R^{2}\right)$ of the entrepreneurial orientation variable on the SME's performance obtained in the second step is 0.169 , it shows that the entrepreneurial orientation variable can explain the SME's performance $16.9 \%$, so the first hypothesis in this research was accepted. This shows that to achieve maximum business performance, SME's must have a good entrepreneurial orientation. Entrepreneurial orientation can influence SME's performance because entrepreneurial orientation is one of the key elements that refers to the processes, practices, and decision making to improve performance in running a business (Fauni, 2017). The better entrepreneurial orientation owned by SME's, the better business performance will be.

The existence of a high entrepreneurial orientation will encourage SME's to create new ideas, open new opportunities for market penetration and conduct experiments by calculating the level of risk that will be obtained, so that eventually SME's will be able to become market leaders by implementing strategies and long-term goals. The existence of a clear entrepreneurial orientation owned by SME's will be able to improve the performance of their businesses, so that SME's will be able to maintain their existence in a sharper business environment. The results of this research, have provided evidence that entrepreneurial orientation is one of the important instruments in improving business performance in SME's. Entrepreneurship oriented SME's in each of their business activities will be able to mobilize strategic resources to identify every business opportunity that exists.

In the third step shows that the beta coefficient value is 0.329 with a significance value $p<$ 0.001 . This shows that product innovation has a positive and significant effect on the performance of SME's. The delta coefficient of determination value $\left(\Delta R^{2}\right)$ of the product innovation variable on the SME's performance obtained in the third step is 0.103 , it shows that the product innovation variable can explain the SME's performance $10.3 \%$, so the second hypothesis in this research was accepted. These results indicate that with the product innovation carried out by SME's, it will be able to create better business performance on SME's. This shows that the better and more often these SME's innovate well by creating new designs that are more attractive and unique and always control the quality of the products produced, the SME's performance will be improved. The higher intensity of SME's in product innovation, the higher performance of SME's produced (Osei, 2016).

The ability of SME's to innovate their products will enable SME's to create products that are in accordance with the wants and needs of customers. Product innovation by modifying or making new products is necessary for business continuity, especially in forming customer loyalty, so that it will have an impact on increasing the number of customers and increasing product sales. Ndubisi (2014) argues that in a growing business environment, product innovation is needed from businesses to increase the value added of the products. Product innovation is seen as a business mechanism to be able to adapt a dynamic environment. The changes that exist in the business environment require the business people to be able to create new thoughts and offer innovative products. Product innovation has an important role not only as a tool to be maintain the survival of a business, but also to improve the performance of SME's maximally. The results of this research contribute to the importance of product innovation on business. The existence of product innovations carried out by SME's will be able to contribute significantly to the success of the performance achieved by SME's. SME's that have a mainstay product and can create in identity for their business, the performance of business will increase and business growth will be maintained. Product innovation can't be separated 
from the business life because it is a spirit or soul in running a business to be able continue to develop and maintain sustainability in the business run. According Aksoy (2017) said that the better and the more frequent SME's who innovate by creating and developing new ideas, creating attractive designs, adding new products at every opportunity, and actively developing the quality of their products, it will be able to improve the performance of these SME's.

In the fourth step shows that the beta coefficient value is 0.616 with a significance value $p$ $<0.001$. This shows that information technology has a positive and significant effect on SME's performance. The delta value of the coefficient of determination $\left(\Delta R^{2}\right)$ of the information technology variable on the performance of SME's obtained in the fourth step is 0.331 , it shows that the information technology variable can explain the SME's performance $33.1 \%$, so the third hypothesis is accepted. These results indicate that with the use of information technology carried out by SME's, it will be able to create better business performance on SME's. Information technology is like blood and arteries that cannot be separated in running a business. Strategies in business will be more effective if supported by accurate information technology (Anand, 2013).

Information technology has a set of supporting elements in order to realize a better SMEs performance because it is influenced by speed, accuracy, and accuracy. Information technology is useful to reduce costs in business activities, especially for SME's the existence of information technology can be utilized to allocate and save their budgets for other uses (Olusola \& Oluwaseun, 2013). Improving the system and maintaining information technology devices will make SME's more be efficient in operationalizing, obtaining information, and can use it as a promotion to the public so the businesses runs will grow.

Apulu \& Latham (2011) argue that SME's will have good performance if they are able to adopt information technology in carrying out their business activities. SME's will benefit greatly if they have a level of understanding in applying information technology doing business because with information technology, SME's will be more adaptive in dealing with dynamics in the business environment. Thus, by utilizing information technology, SME's will be able to easily enter the market, so SME's will easily sell their products and will ultimately have an impact on the increasing level of product sales and the level of income generated by SME's. The use of information technology will also enable SME's to work more efficiently so that the performance of SMEs will improve. The results of this research are consistent with the results of previous studies conducted by Adietya (2017) which states that information technology has a positive effect on the performance of SME's, with the maximum utilization of information technology will be able to improve the performance of SME's.

In the fifth step shows that the beta coefficient value is 0.872 with a significance value $p<$ 0.001 . This shows that intellectual capital has a positive and significant effect on SME's performance. The delta value of the coefficient of determination $\left(\Delta R^{2}\right)$ of the intellectual capital variable on the performance of SME's obtained in step five is 0.655 , it shows that the intellectual capital variable can explain the SME's performance $65.5 \%$, so the fourth hypothesis in this research was accepted. Intellectual capital (intellectual capital) can affect the performance of SME's because intellectual capital is one of the main assets that determines success in running a business (Bontis, 2004). Ferreira (2007) success in running a business is determined by the resources owned and the capability of a business organization to convert existing resources into economic benefits and the success or failure of a business is determined by the strengths and weaknesses that exist in the internal business.

The component of intellectual capital which includes human capital, structural capital, and relationship capital will have an impact on increasing product sales, number of customers, and the 
INTERNATIONAL JOURNAL OF ACADEMIC RESEARCH IN BUSINESS AND SOCIAL SCIENCES Vol. 10, No. 8, 2020, E-ISSN: 2222-6990 @ 2020 HRMARS

level of income obtained by SME's. The results of this research contribute the importance of managing intellectual capital in running a business. The existence of good intellectual capital management, will be able to make a significant contribution to the success of business performance achieved. Good intellectual capital management will be able to form a unique SME's resources and difficult to imitate competitor, and can develop continuously and sustainably, so SME's will be able to achieve better business performance.

In the sixth step, it was found that intellectual capital mediated the effect of entrepreneurial orientation on SME's performance, indicated from the beta coefficient value of entrepreneurial orientation after the intellectual capital variable was included, from $0.418(p<0.001)$ to 0.121 ( $p<$ $0.05)$, so the fifth hypothesis in this research was accepted. This shows that entrepreneurial orientation doesn't directly affect the SME's performance, but through the presence of intermediaries from intellectual capital owned by the SME's. SME's performance will improve, if SME's have an entrepreneurial orientation and good intellectual capital management. The results of this research provide an understanding that with a good intellectual capital management, it will create a good entrepreneurial orientation, so as to create better business performance in SME's. The SME's performance will be able to increase if on running the business, SME's have entrepreneurial orientation and supported by the existence of good intellectual capital management. It is similar with the Resource-Based View theory proposed by Barney (2001) where in that theory is stated that a business can excel in business competition and will obtain good performance, if it has, mastering, and utilizing strategic assets owned by the company. Thus, through superior resource ownership, SME's will be able to carry out the right business strategies, which will ultimately be able to improve business performance on SME's.

Intellectual capital mediates the effect of product innovation on the performance of SME's, this is indicated from the beta coefficient value of product innovation after the intellectual capital variable has been entered, from $0.329(p<0.001)$ to $0.107(p<0.05)$, so the sixth hypothesis in this research was accepted. These results show that product innovation doesn't directly affect the SME's performance, but through the intellectual capital intermediary. In creating product innovation, required the role of intellektual capital that has reliable competence to improve the SME's performance. Product innovation that supported by the ability of SME's to maximize intellectual capital performance, will be able to improve the business performance of SME's. Terziovski (2010) argues that intellectual capital is needed in an effort to build a product innovation. Therefore, to make a product innovation, the role of intellectual capital is needed. Increasing excellence through product innovation and good intellectual capital management will have a good impact on SME's performance. Product innovation cannot be separated from the intellectual capital role owned by SME's. The higher product innovation shows the better of intellectual capital management on SMEs, which will have an impact on the higher opportunities to increase competitive advantage as indicated by an increase in business performance in SME's.

Intellectual capital mediates the effect of information technology on the performance of SME's, this is indicated from the beta coefficient value of information technology after the intellectual capital variable has been entered, from $0.616(p<0.001)$ to $0.190(p<0.001)$, so the seventh hypothesis is accepted. This shows that information technology affects the performance of SME's indirectly through intermediaries from intellectual capital. The ability of SME's to use information technology shows that there is good intellectual capital management which has an impact on improving SME's performance. Utilization of information technology accompanied by the ability of 
SME's to maximizing the performance of intellectual capital, it will be able to improve the SME's performance.

This is in accordance with the opinion of Belkaoui (2003) which states that the potential strategy in improving business performance is to manage strategic assets within an organization. Resource based view are development theory of management strategic and competitive advantage of companies that believe that a company will achieve excellence if it has superior resources (Solikhah, 2010). Based on this approach it can be concluded that by managing the resources owned by SME's well, it will affect business performance. Therefore, it is important for SME's to be able to manage their intellectual capital in order to support the process of implementing information technology in order to improve SME's performance.

\section{Conclusion And Recommendation}

From the results of the research it can be concluded that the entrepreneurial orientation, product innovation, information technology, and intellectual capital have a major contribution to the SME's performance especially in the era of industrial revolution 4.0. The SME's performance will increase if SME's can implement maximally the resource-based view, that is by managing the entire potential internal resources that are owned appropriately in running the business especially intellectual capital resources. Therefore, to maximize the SME's performance, SME's need to pay attention to aspects of entrepreneurial orientation, product innovation, utilization of information technology, and good intellectual capital management. In addition, training and development programs from the government for SME's are also needed, so that they are able to manage their businesses better. Besides that, there is also a need for transfer technology for SME's, because this is necessary for SME's to survive, especially in the era of the industrial revolution 4.0

\section{Theoretical Contribution}

The results of this study are accordance with the results of previous studies which state that entrepreneurial orientation, product innovation, information technology affect the SME's performance. In addition, in this study, the results show that the intellectual capital variable becomes a mediating variable between entrepreneurial orientation, product innovation, and information technology with the SME's performance. This proves that resources in the form of intellectual capital have an important role for SME's in improving their business performance.

Theoretically, the resource-based view (RBV) which is an applied theory in the field of management strategic, is relevant to this research and the resource-based view (RBV) is also needed for SME's in doing business. The SME's performance will increase, if SME's can optimally apply a resource-based view, namely by properly managing all potential internal resources in running their business, especially resources in the form of intellectual capital. So, it can be concluded that the concept of RBV is considered important to explain the phenomena related to entrepreneurial orientation, product innovation, information technology, and intellectual capital in order to improve business performance in SME's.

\section{Managerial Contributions}

Based on the results of the research that has been done, there are several managerial implications for SME's in running a business, a business actor needs to have a good entrepreneurial orientation because this is one of the factors that contribute to supporting the SME's performance. 
INTERNATIONAL JOURNAL OF ACADEMIC RESEARCH IN BUSINESS AND SOCIAL SCIENCES Vol. 10, No. 8, 2020, E-ISSN: 2222-6990 @ 2020 HRMARS

The entrepreneurial orientation will provide additional capabilities that can provide diversity and added value in running a business. In addition, product innovation is also seen as one of the important things to do by SME's, because product innovation is a mechanism in business to adapt a dynamic environment by creating innovative superior products.

Information technology is also one of the factors that business actor need to pay attention, especially in the digital era. The implementation of information technology will greatly benefit business actors, especially for SME's, because with this information technology, SME's will be more adaptive in dealing with the dynamics in the business environment and SME's will be able to easily enter the market, thus enabling SME's to work more efficient. In addition, the awareness of SME's to manage assets in the form of intellectual capital also needs to be considered, because intellectual capital is one of the key factors to achieve progress in business.

Intellectual capital will be able to provide an added value for the sustainability of SME's. The strengthening of intellectual capital will be able to increase self-competence, open insights, strengthen cooperation with other parties, increase the bargaining power of SME's actors and in the end will be able to increase the performance of SME's. Therefore, to be able to maximize the SME's performance, it is necessary to have training and development for SME's, so they are able to better manage their businesses.

\section{Limitations}

This research contains limitations, including the data collection technique that only uses a closed questionnaire, so the choice of answers is not entirely in accordance with the opinions of respondents, in addition there are limitations regarding the scope of the research area. Based on the limitations of the research as described above, the following are some suggested improvements for future researchers : for the future research can use other methods to explore issues in research for example using a mix method that is by combining quantitative and qualitative methods to study existing problems and next researcher is expected to increase the area to provide better research result.

\section{References}

Abbas, D. (2014). The Effect of Business Capital, Market Orientation, and Entrepreneurship Orientation on the Performance of Makassar City SMEs. Journal of Management, Ideas, Inspiration (MINDS), 3(1), 95-111. Retrieved from http://journal.uinalaudin.ac.id/index.php/minds

Adietya, K. (2017). Analysis of the Effects of Information Technology and Innovation on Competitive Advantage to Improve Organizational Performance. Retrieved from http://eprints.undip.ac.id/49162/

Aksoy, H. (2017). How Do Innovation Culture, Marketing Innovation, and Product Innovation Affect the Market Performance of Small and Medium Enterprises (SMEs)?. Technology in Society, 51, 133-141. doi: 10.1108/136830412112

Alipour, M. (2012). The Effect of Intellectual Capital on Firm Performace: An Investigation of Iran Insurance Companies. Measuring Business Excellence, 6(1), 53-66. https:// doi.org/10.1108/136830412112 
INTERNATIONAL JOURNAL OF ACADEMIC RESEARCH IN BUSINESS AND SOCIAL SCIENCES Vol. 10, No. 8, 2020, E-ISSN: 2222-6990 @ 2020 HRMARS

Al Swidi, A. K., \& Mahmood, R. (2011). How Does Organizational Culture Shape the Relationship Between Entrepreneurial Orientation and Organizational Performance? European Journal of Social Science, 2(1), 28-46. Retrieved from http://eurojournals.com/EJSS_20_1_03

Anand, A., Wamba, S. F., \& Sharma, R. (2013). The Effect of IT Capabilities on Firm Performance Evidence from the Healthcare Industry. University of Wollongong. 24 ${ }^{\text {th }}$ Australian Conference on Information System, 4-6 December, Melbourne.

Anggadwita, G., \& Mustafid, Q. Y. (2013). Identification of Factors Influencing the Performance of Small Medium Enterprises (SMEs). Procedia Social and Behaviour Sciences, 115, 415423.https://doi.org/ 10.1016/j.sbspro.2014.02.448

Apulu, I., \& Latham, A. (2011). A Driver for Information and Communication Technology Adoption: A Case Study of Nigerian Small and Medium Enterprises. International Journal of Business and Management, , 6(5), 51-60. doi:10.5539/iijbm.v6n5p51

Atalay, M., Anafarta, N., \& Sarvan, F. (2013). The Relationship Between Innovation and Firm Performance: An Empirical Evidence From Turkish Automotive Supplier Industry, ProcediaSocial and Behavioral Sciences, 75(2), 226-235.https:// doi.org/10.1016/j.sbspro.2013.04.026

Awang, A., Khalid, S. A., Yusof, A., Kasim, K. M., Ismail, M., Zain, R. S., \& Madar, A. R. (2009) Entrepreneurial Orientation and Performance Relation of Malaysian Bumiputera SME's The Impact of Some Percieve Enviromental Factors. International Journal of Business and Management, 4(9), 84-96. http://ccsenet.org/journal.html

Barney, J., Wright, M., \& Ketchen, D. J. (2001). The Resource-Based View of the Firm: Ten Years After 1991. Journal of Management, 27(6), 625-641. doi: 10.1177/014920630102700601

Belkaoui, A. R. (2003). Intellectual Capital and Firm Performance of U.S. Multinational Firms : A Study of the Resource-Based and Stakeholder Views. Journal of Intellectual Capital, 4(2), 215-226. doi: $10.1108 / 14691930310472839$

Bontis, N. (2004). National Intellectual Index: A United Nation Initiative for the Arab Region. Journal of Intellectual Capital, 5(1), 13-39.https://doi.org/10.1108/14691930410512905

Dahnil, M., Mizal, K., Langgat, J., \& Fabeli, N. F. (2014). Factors Influencing SMEs Adoption of Social Media Marketing. In Procedia - Social and Behavioral Sciences, 148(1), 119126.https://doi.org/10.1016/j.sbspro.2014.07.025

Fauni, A. M. (2017). Factors Influencing The Business Performance of SMES Convection in Kudus. Journal of Economic Education, 6(2), 124-133.https://doi.org/10.1594/jeec.v6i2.19298

Ferreira, J., \& Azevedo, S. (2007). Entrepreneurial Orientation as A Main Resource and Capability on Small Firm's Growth, MPRA Paper, 5682, 1-20. https://mpra.ub.uni-muenchen.de/5682/

Frank, H., Kessler, A., \& Fink, M. (2010). Entrepreneurial Orientation and Business Performance- A Replication Study. Schmalenbach Business Review, 62(2), 175-198. http://doi.org/ 10.1007/BF03396804

Ghozali, I. (2011). Aplikasi Analisis Multivariate Dengan Program SPSS. Semarang: Badan Penerbit Universitas Diponegoro.

Herlambang, G., dan Mawardi, M. K. (2017). Pengaruh Orientasi Pasar dan Inovasi Produk Terhadap Kinerja UKM. Jurnal Administrasi Bisnis, 49(2), 56-62. http://administrasibisnis.studentjournal.ub.ac.id/index.php/jab/article/view/1919

Herman, M., Pentek, T., \& Otto, B., (2016). Design Principles for Industrie 4.0 Scenarios. In 49th Hawaii International Conference on Systems Science, 3928-3937. 
INTERNATIONAL JOURNAL OF ACADEMIC RESEARCH IN BUSINESS AND SOCIAL SCIENCES Vol. 10, No. 8, 2020, E-ISSN: 2222-6990 @ 2020 HRMARS

Indriastuti, M. (2012). Peningkatan Kinerja UKM Dengan Pengolahan Intellectual Capital dan Inovasi. Proceedings of Conference in Business, Accounting, and Management (CBAM), 1(1), 649-661. Jayaningrum, E. (2018). Pengaruh Orientasi Pasar, Inovasi, Orientasi Kewirausahaan, Terhadap Keunggulan Bersaing dan Kinerja Pemasaran (Studi pada Kuliner Kafe Kota Malang). Jurnal Administrasi Bisnis, 54(1), 149-158.

Karami, M., \& Tang, J. (2019). Entrepreneurial Orientation and SME International Performance: The Mediating Role of Networking Capability and Experiental Learning. International Small Business Journal, 27(2), 105-124.https://doi.org/10.1177/0266242618807275

Lie, Y., Zhao, Y., Tan, J., \& Liu, Yi. (2008). Moderating Effects of Entrepreneurial Orientation on Market Orientation Performance Linkage: Evidence from Chinese Small Firms. Journal of Small Business Management, 46(1), 13-133.https://doi.org/10.1111/j.1540-627X.2007.00235.x

Mahmood, R., \& Hanafi, N. (2013). Entrepreneurial Orientation and Business Performance of Women-Owned Small and Medium Enterprises in Malaysia: Competitive Advantage as Mediator. International Journal of Business and Social Science, 4(1), 82-91. https://www.researchgate.net/publication/309293520

Matsuno, K., Mentzer, J. T., \& Ozsomer, A. (2002). The Effect of Entrepreneurial Proclivity and Market Orientation on Business Performance. Journal of Marketing, 66(3), 1832.https://doi.org/10.1509/jmkg.66.3.18.18507

Ndubisi. (2014). Entrepreneurship and Service Innovation. Journal of Business \& Industrial Marketing, 29, 449-453. doi: 10.1108/JBIM-07-2013-0148

Olusola, A., \& Oluwaseun, Y. (2013). An Appraisal of the Impact of Information Technology (IT) on Nigeria Small and Medium Enterprises (SMEs) Performance. International of Academic Research in Management (IJARM), 2(4), 140-152.

Osei, A., Yunfei, S., Appienti, W. A., \& Forkuoh, S. K. (2016). Product Innovation and SMEs Performance in the Manufacturing Sector of Ghana. British Journal of Economics, Management \& Trade, 15(3), 1-14.https://doi.org/ 10.9734/BJEMT/2016/29906

Prasetyo, H., \& Sutopo, W. (2018). Industri 4.0: Telaah Klasifikasi Aspek dan Arah Perkembangan Riset. Jurnal Teknik Industri, 13(1), 17-26.https://doi.org/10.14710/jati.13.1.17-26

Terziovski, M. (2010). Achieving Performance Excellence Through an Integrated Strategy of Radical Innovation and Continous Improvement. Measuring Business Excellence, 6(2), 514.https://doi.org/10.1108/13683040210431419

Wardi, Y., \& Susanro, P. (2015). Analisis Orientasi Kewirausahaan Pada Kinerja Perusahaan Studi Empiris pada UKM di Sumatera Barat. Seminar Nasional Ekonomi Manajemen dan Akuntansi Fakultas Ekonomi Universitas Negeri Padang. 